\title{
ANALISIS KEBUTUHAN PENGEMBANGAN BAHAN AJAR IPA TERPADU BERMUATAN LITERASI ERA DIGITAL UNTUK PEMBELAJARAN SISWA SMP KELAS VIII
}

\author{
Asrizal $^{1)}$, Festiyed ${ }^{1)}$, Ramadhan Sumarmin ${ }^{3)}$ \\ ${ }^{1)}$ Jurusan Fisika FMIPA Universitas Negeri Padang \\ ${ }^{2)}$ Jurusan Fisika FMIPA Universitas Negeri Padang \\ ${ }^{3)}$ Jurusan Biologi FMIPA Universitas Negeri Padang \\ Asrizal unp@yahoo.com
}

\begin{abstract}
Science learning should be able to develop the ability to think, to work, to use tools, and to live in the world for students. Integrated Science learning and integration of digital age literacy give good opportunities for students to develop fourth of these skills. But the reality shows that the implementation of integrated science learning and integration of literacy in learning can't be implemented well. An alternative solution of this problem is to develop integrated science learning by integrating digital age literacy. Before developing this integrated science materials it is necessary to conduct preliminary research as a basis for designing this learning materials. The purpose of this preliminary research is to describe the integration of knowledge basic competencies of science subjects, the implementation of integrated science learning, the learning materials available for science learning, and the integrating literacy of students. The type of research was descriptive research method. As object of the research consist of science teachers, syllabus and science learning materials, and students of grade VIII in junior high school. Instruments to collect data consist of interview guide sheet, science syllabus and learning materials document, and digital age literacy test sheet. Research data was analyzed with descriptive statistic. Base on data analysis can be stated that results of this research are: 1). integrated science learning on grade VIII junior high school students can't be implemented well, 2). the value of integration of science learning materials and its application in knowledge basic competence can be classified into enough category, 3). generally science learning materials in integrated science textbooks and science worksheet on grade VIII junior high school are still separated form, and 4). the average value of digital age literacy of students is classified into low category.
\end{abstract}

Keywords : Need Analysis, Learning Material, Integrated Science, Digital age literacy

\section{PENDAHULUAN}

Pembelajaran yang dilaksanakan seharusnya mampu mempersiapkan lulusan agar mampu menghadapi abad ke-21 dengan baik. Lulusan pendidikan seharusnya memiliki kemampuan yang memadai untuk dapat eksis pada abad ke-21. Setidaknya ada empat kemampuan yang perlu dimiliki oleh lulusan pendidikan dalam abad ke-21 yaitu: cara-cara berpikir, cara-cara bekerja, alat-alat untuk bekerja, dan keterampilan-keterampilan untuk hidup dalam dunia. Dengan alasan ini, pembelajaraan yang dilaksanakan guru semestinya dapat membekali siswa pada keempat kemampuan yang dibutuhkan dalam abad ke-21 (Paige, 2016).

Dalam pembelajaran, literasi sangat pen ting bagi siswa karena keterampilan dalam literasi berpengaruh terhadap keberhasilan belajar dan kehidupan mereka. Keterampilan literasi yang baik akan membantu siswa dalam mema- hami berbagai sumber belajar baik teks lisan, tulisan, maupun visual (RTI, 2014). Keterampilan literasi berperan penting dalam menentukan keberhasilan siswa dalam proses pembelajaran.

Sebagai contoh, literasi saintifik merupakan arena penting untuk membantu siswa dalam menyikapi dan mengambil keputusan yang berhubungan dengan permasalahan IPA dalam kehidupannya. Literasi saintifik adalah penting karena suatu pemahaman dari IPA menyediakan pemenuhan dan kegembiraan pribadi siswa. Heller menyatakan empat alasan bahwa literasi saintifik penting dalam kehidupan. Pertama, daya saing dan kemampuan kerja terkait erat dengan kapasitas individu untuk berpartisipasi secara aktif dan mempromosikan inovasi. Kedua, dalam abad ke-21 IPA dan teknologi telah memainkan peran penting dalam banyak bidang di masyarakat. Ketiga, banyak masalah sosial terbesar saat ini melibatkan komponen ilmiah 
dan teknologi yang penting. Terakhir, dunia membutuhkan warga negara dengan keterampilan berpikir kritis (Ogunkola, 2014).

Bertitik tolak pada karakteristik dari IPA seharusnya pembelajaran IPA dilakukan secara terpadu. Dengan alasan ini, kurikulum 2013 menuntut pembelajaran IPA dilakukan secara terpadu di SMP/MTs. Dalam pendekatan konten kurikulum tahun 2013, kompetensi siswa di SMP dikembangkan melalui mata pelajaran terpadu dan tematik. Di sisi lain dalam elemen proses pembelajaran, IPA diajarkan dalam bentuk pembelajaran terpadu. Isi pembelajaran di SMP didasarkan pada konsep terpadu dari berbagai disiplin ilmu untuk tujuan pendidikan dari mata pelajaran IPA. Konsep terpadu dalam IPA ini ditunjukkan pada kompetensi inti dan kompetensi dasar. Dalam kompetensi dasar telah memadukan konsep-konsep IPA dari sub disiplin dari Biologi, Fisika, Kimia, serta Ilmu Bumi dan Antariksa.

Dari segi ilmu psikologi dan pendidikan, seorang siswa akan lebih mudah mengenal dan memahami benda-benda di alam secara keselu ruhan terlebih dahulu dibandingkan dengan melalui bagian-bagiannya yang terkecil. Pembe lajaran IPA terpadu sangat sesuai diterapkan untuk siswa SMP dibandingkan jika diberikan secara terpisah. Pembelajaran IPA terpadu diper caya lebih mampu menumbuhkan kreativitas siswa dan lebih menyenangkan.

Pembelajaran IPA terpadu mendukung kerangka pengembangan kurikulum IPA yang mengaitkan IPA dengan kehidupan sehari-hari, lingkungan, dan teknologi. Dalam pembelajaran terpadu, siswa dilatih mengembangkan literasi dalam mengkonstruksi kompetensi secara aktif, autentik, bermakna, dan holistik. Pembelajaran ini relevan dengan salah satu prinsip esensial dari pembelajaran abad ke-21 yaitu pembelajaran seharusnya mempunyai konteks (Nichols, 2015). Artinya materi pembelajaran IPA perlu dikaitkan dengan situasi dunia nyata. Dengan cara ini, pembelajaran IPA terpadu mampu mendukung kerangka pengembangan kurikulum IPA di SMP/MTs.

Namun kenyataan menunjukkan bahwa penerapan pembelajaran IPA terpadu dan in tegrasi literasi dalam pembelajaran belum dapat dilaksanakan dengan baik. Kenyataan pertama ditemukan dari hasil studi literatur tentang IPA terpadu. Dari hasil studi dapat digambarkan bahwa penerapan pembelajaran IPA terpadu di SMP mengalami berbagai kendala. Kendala per- tama adalah sajian buku yang menggunakan label IPA terpadu masih sekedar formalitas, sementara isi buku tersebut cenderung mengacu pada salah satu bidang kajian IPA (Yulianti, 2013).

Kenyataan kedua adalah rendahnya penguasaan guru terhadap IPA terpadu sehingga pembelajaran IPA terpadu belum terlaksana. Hasil penelitian menunjukkan bahwa: 1). IPA terpadu belum dilaksanakan di wilayah propinsi DIY, 2). guru IPA SMP/MTs di wilayah DIY belum memahami bahwa IPA terpadu adalah strategi pembelajaran yang lebih efektif dan efisien, menggunakan pendekatan tematik, 3). guru mengalami kendala dalam pembelajaran IPA terpadu (Maryati, 2012).

Kenyataan ketiga ditemukan dari hasil literasi sains siswa. Dari laporan PISA diketahui bahwa hasil literasi sains siswa di Indonesia belum memuaskan. Skor literasi sains siswa Indonesia pada tahun 2009 adalah 383 dengan skor tertinggi 575. Siswa Indonesia menempati peringkat 57 dari 65 negara peserta (Gurria, 2010). Pada tahun 2012, skor lieterasi sains siswa Indonesia adalah 382 dengan skor tertinggi 501. Siswa Indonesia menempati peringkat 64 dari 65 negara peserta (Gurria, 2014). Dari kedua hasil laporan PISA ini dapat dikemukakan bahwa literasi sains siswa SMP di Indonesia masih rendah.

Bertitik tolak pada kondisi ideal dan kondisi nyata yang telah diuraikan ditemukan adanya permasalahan dalam pembelajaran IPA terpadu. Adanya upaya untuk mengatasi permasalahan ini penting dilakukan. Sebagai salah satu solusi untuk memecahkan permasalahan ini adalah mengembangkan bahan ajar IPA terpadu bermuatan literasi era digital. Solusi ini sesuai dengan rancangan kurikulum di SMP yang menyatakan bahwa proses pembelajaran IPA diajarkan secara terpadu.

Dari solusi ini ada tiga kajian teori yang perlu dilakukan. Kajian teori pertama adalah bahan ajar. Bahan ajar (teaching materials) adalah suatu istilah generik yang digunakan untuk menggambarkan penggunaan sumber belajar oleh guru untuk menyampaikan pembelajaran. Dengan cara ini, bahan ajar dapat mendukung belajar siswa dan meningkatkan keberhasilannya. Bahan ajar dapat didefinisikan sebagai urai an dari seperangkat materi yang disusun secara sistematis baik tertulis maupun tidak tertulis sehingga tercipta lingkungan atau suasana yang memungkinkan siswa untuk belajar (Wahyuni, 
2015). Pengertian lain dari bahan ajar adalah segala bentuk bahan atau materi yang disusun secara sistematis yang digunakan untuk membantu guru atau instruktur dalam melaksanakan kegiatan belajar mengajar sehingga tercipta lingkungan atau suasana yang memungkinkan siswa untuk belajar (Aditia, 2013).

Bahan ajar merupakan sumber belajar esensial dan penting yang diperlukan pembelajaran dari mata pelajaran di sekolah untuk mendorong efisien guru dan meningkatkan kinerja siswa. Dengan bahan ajar membuat pembelajaran lebih menarik, praktis, dan realistik. Disamping itu penggunaan bahan ajar dalam pembelajaran memungkingkan baik guru dan siswa dapat berpatisipasi secara aktif dan membuat pembelajaran lebih efektif. Bahan ajar dapat memberikan ruang untuk memperoleh pengetahuan dan keterampilan, mengembangkan kepercayaan diri dan aktualisasi diri siswa (Olayinka, 2016).

Penggunaan bahan ajar dalam pembelajaran dapat memberikan keuntungan kepada siswa. Ada beberapa keuntungan penggunaan bahan ajar yaitu: 1). membuat siswa berpartisipasi dengan kreatif dan berpikir analitis ketika mereka dilibatkan dalam pembelajaran, 2). konsepkonsep yang dipelajari menggunakan bahan ajar menjadi lebih jelas bagi siswa karena konsep tersebut diajarkan melalui kegiatan belajar, 3). mendorong suatu integrasi yang sistematis dari variasi sumber dalam suatu pengalaman belajar, 4). menjadi terlibat secara aktif dalam improvisasi, prinsip kerja dipelajari dan dengan cara ini adanya siswa memperoleh keterampilan pemecahan masalah, sikap dan pengetahuan ilmiah yang diperlukan dalam pemecahan masalah ilmiah dan teknologi (Akani, 2016).

Kajian teori kedua adalah berhubungan dengan pembelajaran IPA terpadu. IPA Terpadu merupakan IPA yang disajikan sebagai satu kesatuan yang tidak terpisahkan, artinya siswa tidak belajar ilmu Fisika, Biologi, dan Kimia secara terpisah sebagai mata pelajaran yang berdiri sendiri, melainkan semua diramu dalam kesatuan (Das, 2009). Dengan kata lain IPA Terpadu adalah pembelajaran IPA yang mencoba memadukan beberapa pokok bahasan dari berbagai bidang kajian seperti Fisika, Kimia, Biologi, Bumi dan Alam Semesta pada mata pelajaran IPA dalam satu bahasan (Nomini, 2015). Melalui pembelajaran ini siswa dapat mempelajari tentang alam beserta fenomena yang terjadi didalamnya secara utuh. Cara ini memungkinkan siswa aktif mencari, menggali, dan menemukan konsep IPA dalam kehidupan (Suhartatik, 2016).

Pembelajaran terpadu menggunakan suatu pendekatan interdisipliner dari mata pelajaran dapat didesain dalam bentuk tema atau konsep terintegrasi. Sebagai contoh dalam bidang IPA, mata pelajaran IPA dapat dilakukan secara bersamaan dengan topik mencakup Biologi, Kimia, dan Fisika (Yarker, 2012). Keterpaduan dalam IPA dapat membantu siswa untuk memperoleh penguatan suatu pemahaman dari peran dan fungsi IPA dalam kehidupan sehari-hari dan dunia dimana mereka hidup (Afuwave, 2012: 127). Dengan pembelajaran IPA terpadu pembelajaran lebih dekat dengan kehidupan siswa.

Kajian teori ketiga berhubungan dengan literasi siswa. Literasi (literacy) berhubungan dengan suatu kompetensi dalam suatu bidang yang diberikan. Sebagai contoh, literasi membaca adalah kemampuan untuk membaca pada suatu level fungsional (Ronis, 2001). Era digital (digital era) adalah suatu istilah masa yang digunakan untuk menggambarkan teknologi digital. Dengan demikian literasi era digital (digital age literacy) dapat didefinisikan sebagai kemampuan dalam bidang tertentu yang dapat digunakan pada zaman teknologi digital.

Literasi era digital membahas literasi dasar, saintifik, dan teknologi, literasi visual dan informasi, dan literasi budaya dan kesadaran global (Yildiz, 2010). Dengan kata lain literasi era digital terdiri dari literasi fungsional, literasi fungsional, literasi saintifik, literasi teknologi, literasi informasi, literasi budaya, dan kesadaran global (Shafeeq, 2013). Literasi ini merupakan salah satu domain utama yang perlu mendapatkan perhatian di dunia pendidikan saat ini (Afandi, 2016).

Bertitik tolak pada latar belakang masalah yang telah diuraikan dapat dikemukakan bahwa penelitian pendahuluan (preliminary research) untuk mengembangkan bahan ajar IPA terpadu bermuatan literasi era digital perlu dilakukan. Tujuan dari penelitian adalah untuk: mendesripsikan keterpaduan kompetensi dasar dari mata pelajaran IPA, penerapan pembelajaran IPA terpadu, bahan ajar yang tersedia untuk pembelajaran, dan literasi siswa.

\section{METODE PENELITIAN}

Penelitian yang dilakukan dapat dimasukkan kedalam jenis penelitian deskriptif. Penelitian deskriptif merupakan metode penelitian yang berusaha menggambarkan dan menginter- 
pretasikan objek sesuai dengan apa adanya. Pada umumnya penelitian deskriptif yang dilakukan memiliki dua tujuan utama yaitu menggambarkan secara sistematis fakta dan karakteristik objek yang diteliti secara tepat (Sukardi, 2004).

Dalam penelitian awal ini ada tiga objek yang diselidiki yaitu guru IPA, silabus dan bahan ajar IPA SMP, dan siswa SMP kelas VIII. Guru IPA SMP kelas VIII digunakan untuk mendapatkan informasi tentang penerapan pembelajaran IPA terpadu di sekolah. Ada enam guru IPA dari tiga SMP Negeri di kota Padang yang diwawancarai untuk mendapatkan informasi ini. Silabus dan bahan ajar merupakan objek kedua untuk mendapatkan informasi adanya keterpaduan materi pembelajaran IPA dan penerapannya. Disisi lain siswa pada tiga SMP Negeri di kota Padang digunakan untuk mendapatkan informasi literasi era digital. Jumlah siswa yang terlibat dalam pengumpulan informasi ini adalah 84 orang. Pada setiap SMP Negeri terlibat 28 orang siswa.

Teknik pengumpulan data yang digunakan dalam penelitian pendahuluan ini terdiri dari tiga bagian yaitu wawancara, dokumentasi, dan tes literasi. Wawancara digunakan untuk mendapatkan data tentang pelaksanaan pembelajaran IPA terpadu oleh guru IPA. Instrumen yang digunakan adalah lembar pedoman wawancara. Dokumentasi digunakan untuk mendapatkan data tentang keterpaduan materi pembelajaran IPA dan penerapannya. Dokumen yang digunakan mencakup silabus, buku IPA terpadu, dan LKS IPA SMP kelas VIII. Instrumen yang digunakan adalah lembar penilaian dokumen. Tes literasi digunakan untuk mendapatkan mendapatkan gambaran tentang literasi era digital siswa. Instrumen yang digunakan adalah lembar tes literasi siswa.

Data yang dikumpulkan melalui instrumen yang sesuai dianalisis dengan menggunakan teknik analisis tertentu. Teknik analisis data yang digunakan dalam penelitian ini adalah analisis statistik deskriptik. Statistik deskriptif adalah statistik yang berfungsi untuk mendeskripsikan atau member gambaran terhadap objek yang diteliti melalui data sampel atau populasi sebagaimana adanya. Pada statistik deskriptif ini tanpa melakukan analisis dan membuat kesimpulan yang berlaku untuk umum. Ada beberapa penyajian data dalam statistik deskriptif yang dapat digunakan seperti: tabel biasa, distribusi frekuensi, grafik, dan penjelasan kelompok data melalui modus, median, nilai rata-rata, variasi kelompok dan standar deviasi (Sugiyono, 2014).

\section{HASIL DAN PEMBAHASAN}

\section{Hasil Penelitian}

Hasil pertama dari penelitian pendahuluan adalah pelaksanaan pembelajaran IPA terpadu. Teknik dan instrumen pengumpul data yang digunakan masing-masing wawancara dan instrumen wawancara. Wawancara dilakukan dengan 6 orang guru IPA SMP Negeri di Kota Padang. Setiap SMP Negeri terdiri dari 2 orang guru IPA. Komponen wawancara tentang penerapan pembelajaran IPA terpadu terdiri dari 6 aspek yaitu: 1). pandangan guru IPA terhadap pembelajaran IPA terpadu, 2). pelaksanaan pembelajaran IPA terpadu, 3). cara memadukan IPA dalam pembelajaran, 4). contoh pembelajaran IPA terpadu yang telah diterapkan, 5). permasalahan yang dihadapi dalam menerapkan pembelajaran IPA terpadu, dan 6). faktor-faktor penyebab permasalahan dalam menerapkan pembelajaran IPA terpadu.

Dari analisis terhadap hasil wawancara dapat dinyatakan 6 hasil. Hasil pertama 66,67 \% guru IPA menyatakan bahwa pembelajaran IPA terpadu menarik atau bagus sedangkan 33,33 \% guru menyatakan pembelajaran IPA terpadu sulit diterapkan. Hasil kedua semua guru IPA menyatakan telah menerapkan pembelajaran IPA terpadu, tetapi pelaksanaan pembelajaran IPA terpadu belum baik. Hasil ketiga adalah 33,33 \% guru IPA mengalami kesulitan dalam memadukan IPA dalam pembelajara, $50.00 \%$ memadukan sesuai dengan buku teks yang digunakan, dan 16,67 memadukannya melalui tim teaching. Hasil keempat adalah contoh-contoh pembelajaran IPA terpadu antara lain: energi, lingkungan, listrik, dan gerak pada makhluk hidup, sedangkan guru IPA lainnya belum dapat memberikan contoh materi IPA terpadu. Hasil kelima adalah faktor-faktor penyebab permasalahan dalam me nerapkan pembelajaran IPA terpadu antara lain: kurangnya referensi IPA terpadu, kurangnya penguasaan terhadap IPA terpadu, dan latar belakang pendidikan.

Hasil kedua dari penelitian pendahuluan adalah keterpaduan kompetensi dasar dari mata pelajaran IPA SMP. Keterpaduan dianalisis dari empat aspek yaitu Biologi, Fisika, Kimia dan penerapannya. Penerapan dari IPA dilihat dari kehidupan sehari-hari, lingkungan dan teknologi. Kompetensi dasar pengetahuan dari IPA 
SMP kelas VIII semester 1 terdiri dari 6 KD3. KD3 pada semester 1 berhubungan dengan materi sistem gerak pada manusia, gerak dan gaya, konsep usaha dan pesawat sederhana, struktur jaringan tumbuhan dan fungsinya, sistem pencernaan pada manusia, dan zat aditif dan zat adiktif. Nilai keterpaduan KD3 mata pelajaran IPA semester 1 diperlihatkan pada Gambar 1

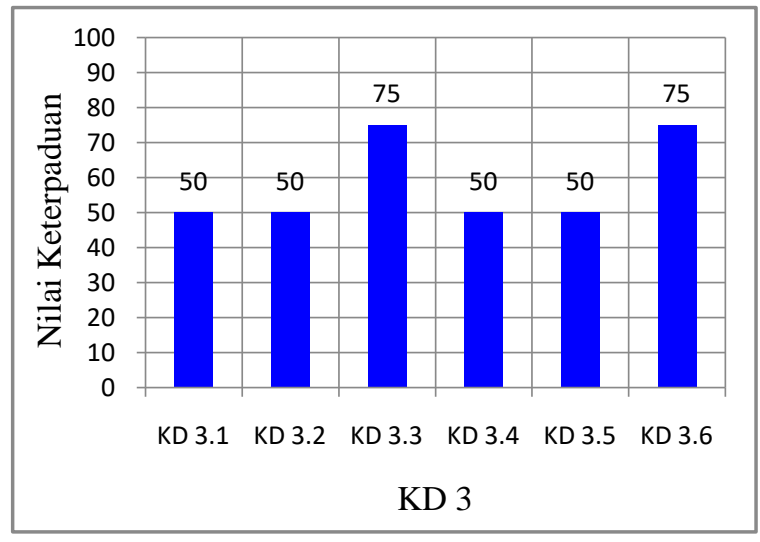

Gambar 1. KD 3 Kelas VIII Semester 1

Dari data untuk setiap KD 3 dapat dijelaskan bahwa ada dua variasi nilai keterpaduan yaitu 50 dan 75 . Nilai 50 berarti ada dua keterpaduan dari IPA yang terdapat pada KD. Sebagai contoh memahami gerak pada makhluk hidup, sistem gerak pada manusia dan upaya menjaga kesehatan sistem gerak. Pada KD sudah ada keterpaduan antara Biologi dan penerapannya dalam kesehatan. Nilai 75 berarti ada 3 keterpaduan yang terdapat dalam KD. Sebagai contoh KD 3.3 memahami konsep usaha, pesawat sederhana dan penerapannya dalam kehidupan sehari-hari serta hubungannya dengan kerja otot pada struktur rangka manusia. Pada KD 3 semester 1 ini sudah ada keterpaduan antara Fisika, Biologi dan penerapannya dalam kehidupan sehari-hari. Nilai rata-rata keterpaduan dari keenam KD3 adalah 58.33. Nilai ini mengindikasikan bahwa tingkat keterpaduan materi IPA dan penerapannya dimasukkan pada kategori kurang.

Kompetensi dasar pengetahuan dari IPA SMP kelas VIII terdiri dari 6 KD3. KD3 pada semester 2 berhubungan dengan materi pembelajaran sistem peredaran darah pada manusia, tekanan zat dan penerapannya, sistem pernafasan pada manusia, sistem eksresi pada manusia, konsep getaran dan gelombang mekanik, dan sifat cahaya dan pembentukan bayangan. Nilai keterpaduan materi pembelajaran IPA dan pene- rapannya untuk KD3 mata pelajaran IPA semester 2 dapat diperhatikan pada Gambar 2

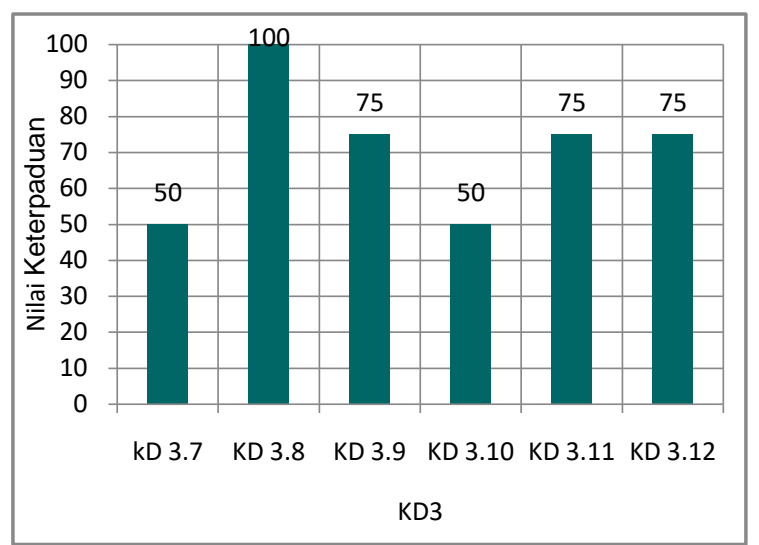

Gambar 2. KD 3 Kelas VIII Semester 2

Dari data pada Gambar 2 dapat dinyatakan bahwa ada tiga variasi nilai keterpaduan materi IPA dan penerapannya dalam KD3 se mester 2 yaitu50, 75, dan 100. Pada semester 2 nilai keterpaduan KD 3 adalah 100. Nilai ini mengindikasikan pada KD3.8 sudah ada keterpaduan dari ketiga bidang IPA dan penerapannya. KD 3.8 adalah memahami tekanan zat dan penerapannya dalam kehidupan sehari-hari, termasuk tekanan darah, osmosis, dan kapilaritas jaringan angkut pada tumbuhan. Kajian Fisika dapat dilihat pada tekanan zat, kajian Biologi dapat dilihat dari penerapan tekanan dalam darah dan sistem jaringan angkut tumbuhan, kajian Kimia diperlihatkan pada penerapan tekanan pada peristiwa osmosis, dan kajian penerapan tekanan zat dalam kehidupan sehari-hari. Nilai rata-rata keterpaduan materi IPA dan penerapannya pada semester 2 adalah 70,83. Nilai ratarata ini mengisyaratkan bahwa keterpaduan materi IPA kelas VIII semester 2 berada pada kategori baik.

Hasil ketiga dari penelitian pendahuluan adalah hasil analisis keterpaduan materi IPA dan penerapannya dalam bahan ajar. Dalam penelitian pendahuluan ini, ada dua jenis bahan ajar yang dianalisis keterpaduannya yaitu buku ajar IPA terpadu dan LKS IPA SMP kelas VIII. Teknik analisis data untuk menganalisis keterpaduan adalah analisis dokumen. Instrumen yang digunakan untuk menganalisis keterpaduan materi pembelajaran IPA dan penerapannya dalam buku ajar adalah lembar penilaian dokumen. Analisis terhadap materi pembelajaran dilakukan untuk setiap bab dari buku IPA terpadu. Hasil analisis materi pembelajaran dari 11 (sebelas) 
buku IPA terpadu SMP kelas VIII diperlihatkan pada Gambar 3.

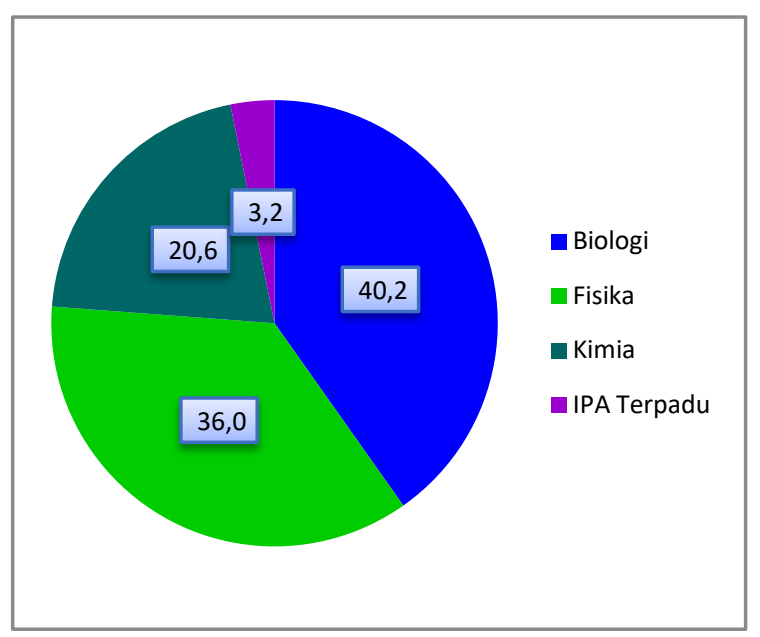

Gambar 3. Keterpaduan Materi dalam Buku Teks IPA Terpadu Kelas VIII

Dari hasil analisis pada Gambar 3 dapat diungkapkan bahwa dari sebelas buku IPA terpadu persentase materi pembelajaran Biologi, Fisika, dan Kimia secara terpisah-pisah masingmasing 40,2 \%, 36,0 \%, dan 20,6 \%. Persentase materi pembelajaran Biologi dan Fisika terlihat lebih banyak dalam buku IPA terpadu. Persentase IPA terpadu hanya 3,2 \% dan keterpaduan ini baru muncul pada buku Ilmu Pengetahuan Alam kurikulum 2013. Hasil analisis ini memberikan isyarat bahwa meskipun judul buku teks sudah IPA terpadu, ternyata keterpaduan materi pembelajaran dalam buku IPA terpadu tersebut masih sangat rendah. Dengan kata lain, umumnya materi pembelajar an dalam buku IPA terpadu masih terpisah-pisah ke dalam bidang Biologi, Fisika, dan Kimia.

Analisis keterpaduan materi pembelajaran IPA juga dilakukan terhadap LKS IPA SMP Kelas VIII. Instrumen yang digunakan untuk menganalisis keterpaduan materi pembelajaran IPA dan penerapannya dalam LKS IPA Fisika dan IPA Biologi adalah lembar penilaian dokumen. Analisis terhadap materi pembelajaran dilakukan untuk setiap LKS yang terdapat dalam LKS IPA Fisika dan LKS Biologi. Pada LKS IPA Fisika dan LKS IPA Biologi untuk SMP/MTs semester 1 masing-masing terdapat lima 5 LKS. Sementara itu pada LKS IPA Fisika dan IPA Biologi untuk SMP/MTs semester 2 masing-masing terdapat lima dan sembilan LKS. Hasil analisis keterpaduan materi pembelajaran IPA dan penerapannya dari LKS IPA Fisika kelas semester 1, LKS IPA Biologi kelas VIII semester 1, LKS IPA Fisika kelas VIII semester 2, dan LKS IPA Biologi kelas VIII semester 2 ditampilkan pada Gambar 3.

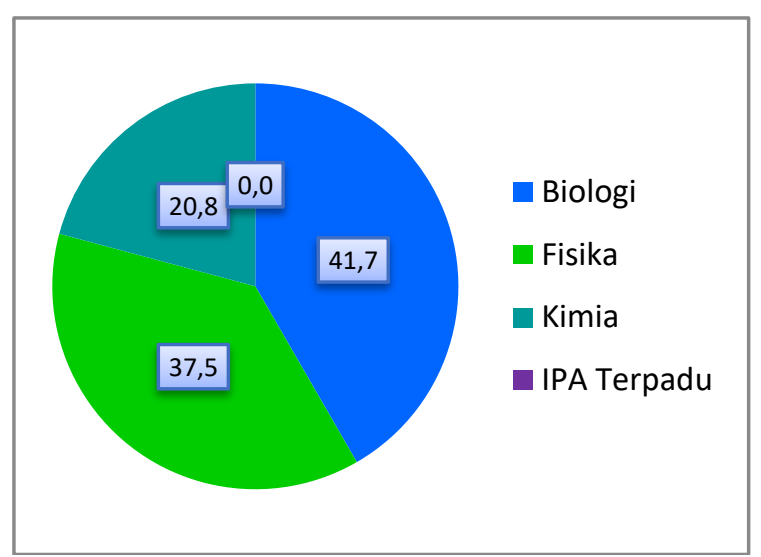

Gambar 4. Keterpaduan Materi dalam LKS IPA Kelas VIII

Berdasarkan hasil analisis data pada Gambar 4 dapat dinyatakan bahwa dari LKS IPA Fisika dan LKS IPA Biologi persentase materi pembelajaran Biologi, Fisika, dan Kimia secara terpisah-pisah masing-masing 41,7 \%, $37,5 \%$, dan $20,8 \%$. Persentase materi pembelajaran Biologi dan Fisika terlihat lebih banyak dalam LKS IPA kelas VIII. Materi pembelajaran Kimia umum dimasukkan keda lam LKS IPA Biologi. Dengan demikian materi pembelajaran dalam LKS IPA Fisika dan LKS IPA Biologi umumnya masih terpisah-pisah.

Analisis lebih dalam dilakukan terhadap keterpaduan materi pembelajaran pada setiap LKS yang terdapat dalam LKS IPA Fisika dan LKS IPA Biologi. Dalam analisis ini digunakan rubrik penilaian dengan skor 1 sampai 4 . Dari analisis didapatkan nilai rata-rata keterpaduan materi pembelajaran IPA dalam LKS IPA untuk SMP/ MTs semester 1 dan semester 2 adalah 38,5 . Nilai rata-rata ini mengindikasikan bahwa tingkat keterpaduan materi pembelajaran IPA dan penerapannya dalam LKS IPA Fisika dan LKS IPA Biologi untuk SMP/MTs termasuk pada kategori sangat rendah.

Hasil penelitian awal yang terakhir adalah literasi era digital siswa. Teknik pengumpul data yang digunakan untuk mengetahui literasi siswa adalah tes. Instrumen yang digunakan untuk mengumpulkan data adalah lembar tes literasi siswa. Literasi siswa yang diuji mencakup literasi fungsional, literasi saintifik, dan literasi saintifik. Tes literasi diberikan kepada siswa SMP kelas VIII yang terdiri dari 3 SMP Negeri di Kota Padang. Setiap SMP diambil sampel 1 ke- 
las siswa. Nilai parameter statistik deskriptif dari hasil tes literasi 84 orang siswa dari 3 SMP Negeri dapat diperhatikan pada Tabel 1

Tabel 1. Nilai Parameter Statistik Deskriptif dari Hasil Tes Literasi

\begin{tabular}{|c|l|c|}
\hline No & Paramter Statistik & Nilai \\
\hline 1 & Jumlah Siswa & 84 \\
\hline 2 & Minimum & 25.00 \\
\hline 3 & Maksimum & 70.83 \\
\hline 4 & Jangkauan & 45.83 \\
\hline 5 & Rata-Rata & 44.45 \\
\hline 6 & Median & 45.83 \\
\hline 7 & Modus & 45.83 \\
\hline 8 & Standar Deviasi & 8.88 \\
\hline 9 & Varians & 78.92 \\
\hline
\end{tabular}

Dari data pada Tabel 1 dapat diungkapkan bahwa nilai terendah dari tes literasi adalah 25,0 sedangkan nilai tertinggi adalah 70,8. Angka 25,0 berarti hasil tes literasi berada pada kategori sangat rendah sedangkan angka 70,8 berarti hasil tes literasi berada pada kategori baik. Jangkauan dari hasil tes literasi adalah 45,8. Nilai rata-rata dari tes literasi siswa adalah 44,5. Nilai rata-rata ini mengisyaratkan bahwa literasi siswa berada pada kategori kurang. Nilai yang sering muncul dan nilai tengah dari hasil tes literasi masing-masing adalah 45.8. Kedua nilai ini berada pada kategori kurang.

\section{Pembahasan}

Hasil penelitian ini dapat dijadikan sebagai dasar dalam pengembangan bahan ajar IPA terpadu bermuatan literasi era digital. Dari hasil penelitian pendahuluan pertama diperoleh informasi bahwa penerapan pembelajaran IPA terpadu pada siswa kelas VIII SMP belum dapat dilaksanakan dengan baik sesuai dengan harapan. Guru IPA masih mengalami kesulitan dalam menerapkan pembelajaran IPA terpadu. Ada beberapa faktor yang menyebabkan guru mengalami kesulitan antara lain: kurangnya referensi dari IPA terpadu, kurang menguasai materi IPA terpadu, dan latar belakang pendidikan. Alternatif solusi dari permasalahan ini adalah guru menggunakan bahan ajar IPA terpadu sebagai media dalam pembelajaran. Dalam pembelajaran guru berperan sebagai fasilitator, motivator, pembimbing, pemberi informasi, penilai dan sebagainya. Dalam hal ini, bahan ajar IPA terpadu dapat dijadikan sebagai media bagi guru untuk melaksanakan perannya dalam proses pembelajaran.
Dari hasil penelitian pendahuluan kedua dapat diidentifikasi bahwa kompetensi dasar pengetahuan pada mata pelajaran IPA SMP kelas VIII sudah memuat adanya keterpaduan materi pembelajaran IPA dan penerapannya. Nilai rata-rata kepterpaduan materi pembelajaran dan penerapannya dalam KD3 untuk semester 1 dan semester 2 adalah 64,6 dan nilai ini berada pada kategori cukup. Keterpaduan materi pembelajaran IPA dan penerapannya masih dapat ditingkatkan. Sebagai solusi dari permasalahan ini adalah mengembangan pembelajaran terpadu menggunakan suatu tema dan model terhubung. Dengan tema dapat dilakukan penggabungan antara beberapa KD3.

Hasil dari penelitian pendahuluan ketiga mengindikasikan bahwa keterpaduan materi pembelajaran IPA dan penerapannya dalam buku IPA terpadu, LKS IPA Fisika, dan LKS IPA Biologi adalah sangat rendah. Berarti umumnya materi pembelajaran IPA baik dalam buku IPA terpadu dan LKS IPA masih terpisah-pisah. Sebagai alternatif solusi dari permasalahan ini adalah mendesain keterpaduan materi pembelajaran IPA dan penerapannya. Keterpaduan materi pembelajaran IPA dalam bahan ajar dapat dilakukan dengan beberapa cara antara lain: merumuskan tema dan sub tema, mengaitkan materi pembelajaran dengan situasi dunia nyata, menghubungan materi pada suatu sub tema dengan bidang IPA yang lain, dan menerapkan materi pembelajaran IPA dalam kehidupan sehari-hari, lingkungan, dan teknologi.

Hasil terakhir dari penelitian pendahuluan ini mengisyaratkan bahwa nilai rata-rata literasi era digital siswa SMP kelas VIII adalah rendah. Ada beberapa faktor yang diduga sebagai penyebab dari masalah ini antara lain: siswa belum terbiasa melakukan kinerja dalam literasi ini, pembelajaran kurang mengintegrasikan literasi, bahan ajar kurang mengintegrasikan literasi, dan kurangnya penerapan penilaian kinerja untuk literasi ini. Solusi alternatif dari permasalahan rendahnya literasi siswa adalah mengintegrasikan literasi kedalam bahan IPA terpadu. Sebagai contoh adanya integrasi literasi era digital ke dalam LKS IPA terpadu akan mendorong siswa untuk terlibat secara aktif dalam membaca, menulis, menghitung, menggambarkan informasi, menelaah konsep saintifik, menggunakan proses saintifik, menerapkan konteks saintifik, menafsirkan informasi visual, dan memanfaatkan informasi visual. Dengan cara ini literasi fungsional, literasi saintifik, dan literasi visual dari 
siswa dapat ditingkatkan melalui penggunaan LKS IPA terpadu dalam pembelajaran.

\section{KESIMPULAN}

Dari analisis data yang telah dilakukan dapat dinyatakan empat hasil dari penelitian pendahuluan ini. Pertama, penerapan pembe lajaran IPA terpadu pada siswa kelas VIII SMP belum dapat dilaksanakan sesuai dengan yang diharapkan. Guru IPA masih mengalami kesulitan dan kendala dalam menerapkan pembe lajaran IPA terpadu. Kedua, nilai rata-rata keterpaduan materi pembelajaran IPA dan penerapannya dalam kompetensi dasar pengetahuan atau KD3 termasuk pada kategori cukup. Hal ini berarti pada KD3 sudah memuat keterpaduan materi pembelajaran IPA dan penerapannya. Ketiga, umumnya materi pembelajaran IPA dalam buku IPA terpadu dan LKS IPA SMP kelas VIII masih terpisah-pisah. Keterpaduan materi pembelajaran IPA dan penerapannya baru terlihat pada buku Ilmu Pengetahuan Alam kurikulum 2013. Terakhir, nilai literasi digital siswa dalam bentuk literasi fungsional, literasi saintifik dan literasi visual masih berada pada kategori rendah.

\section{DAFTAR PUSTAKA}

Aditia, M. Taufik. 2013. Pengembangan Modul Pembelajaran Berbasis Sains, Lingkungan, Teknologi, Masyarakat dan Islam (Salingtemasis) Dalam Meningkatkan Hasil Belajar Siswa Pada Konsep Ekosistem Kelas X di SMA NU (Nadhatul Ulama) Lemahabang Kabupaten Cerebon. Jurnal Scientiae Educatia, Volume 2, Edisi 2.

Akani, Omiko. 2016. An Evaluation of Classroom Experiences of Basic Science Teachers in Secondary Schools in Ebonyi State of Nigeria. British Journal of Education Vol.4, No.1, pp. 64-76.

Gurria, Angel. 2010. PISA 2009 Results: What Students Know and Can Do. Student Performance in Reading, Mathematics and Science. Programme for International Students Assessment, OECD.

Gurria, Angel. 2014. PISA 2012 Results in Focus: What 15-year-olds know and what they can do with what they know. Programme for International Students Assessment, OECD.

Ogunkola, Babalola J. 2013. Scientific Literacy: Conceptual Overview, Importance and
Strategies for Improvement. Journal of Educational and Social Research. Vol 3 (1)

Olayinka, Abdu-Raheem Bilqees. 2016. Effects of Instructional Materials on Secondary Schools Students' Academic Achievement in Social Studies in Ekiti State, Nigeria. World Journal of Education. Vol. 6, No. 2.

Maryati, Purwanti Widhy Hastuti, dan Eko Widodo. 2012. Tingkat Pemahaman dan Kesulitan Pelaksanaan Pembelajaran IPA Terpadu SMP/MTS di Daerah Istimewa Yogyakarta. Universitas Negeri Yogyakarta.

Nomini, Rosiana. 2015. Penggunaan Metode Kesebangunan untuk Meningkatkan Kemamampuan Penerapan Konsep Fisika Siswa Kelas VIII SMP PGRI 396 Kelapa Dua Pada Materi Cahaya. Prosiding Seminar Nasional Fisika (E-Journal) SNF, Volume 4.

Paige, Kathryn. 2016. Slowmation: An Innovative Twenty-First Century Teaching and Learning Tool for Science and Mathematics Pre-service Teachers. Australian Journal of Teacher Education, Volume 41, Issue 2

RTI International. 2014. Prioritizing Reform, Innovation, and Opportunities for Reaching Indonesia's Teachers, Administrators, and Students. Pembelajaran Literasi Kelas Awal SD/MI di LPTK. United States Agency for International Development (USAID).

Sugiyono. 2014. Statistika untuk Penelitian. Bandung, Penerbit Alfabeta.

Suhartatik. 2016. Pengembangan Modul IPA SMP Berbasis Guided Discovery untuk Meningkatkan Kemampuan Berfikir Kog nitif dan Hasil Belajar Siswa. Prosiding Seminar Nasional Pendidikan IPA Pascasarjana UM, Vol. 1

Sukardi. 2004. Metodologi Penelitian Pendidikan: Kompetensi dan Praktiknya. Jakarta, Penerbit Bumi Aksara.

Wahyuni, Sri. 2015. Pengembangan Bahan Ajar IPA Untuk Meningkatkan Kemampuan Berpikir Kritis Siswa SMP. Jurnal Materi dan Pembelajaran Fisika (JMPF) Volume 5 Nomor 2.

Yuliati, L. 2013. Efektivitas Bahan Ajar Terpadu Terhadap Kemampuan Berpikir Tingkat Tinggi Siswa SMP. Jurnal Pendidikan Fisika Indonesia 9: 53-57, ISSN: 1693-1246 